\title{
Glutathione Concentration as Affected by Sulfate Supply Level and its Relationship with Sulfate Uptake and Assimilatory Enzymes Activity in Rape Plants
}

\author{
Lu-Shen Li and Tae-Hwan Kim
}

\author{
유채에서 황 공급수준에 따른 글루타치온 함량의 변화가 황산염 \\ 흡수 및 동화관련 효소활력에 미치는 영향 \\ 이노신 · 김태환
}

요 약

\begin{abstract}
유채 (Brassica napus L.)에서 황 공급수준에 따른 글루타치온 함량의 변화가 황 흡수 및 동화관련 효소 활력에 미치는 영향을 규명하고자, $\mathrm{SO}_{4}{ }^{2-}$ 농도를 4 수준 $(0,0.1,1.0$ 및 $2.0 \mathrm{mM})$ 으로 25 시간 처리 한 후 식물조직 내 글루타치온 함량을 측정하고, $\mathrm{SO}_{4}{ }^{2-}$ 흡수, $\mathrm{ATP}$ sulfurylase (ATPS) 및 $O$ acteylserine (thiol) lyase (OASTL) 효소 활력과의 상관관계를 분석하였다. $\mathrm{SO}_{4}{ }^{2-}$ 흡수는 황 공급수준에 따라 평행적인 증가를 보였으나 잎과 뿌리 조직의 단백질 함량은 유의적인 차이가 없었다. ATPS 활 력은 황 공급수준이 $0 \mathrm{mM}$ 에서 $2.0 \mathrm{mM}$ 로 증가함에 따라 유의적으로 감소 $(\mathrm{p}<0.05)$ 하였으며, OASTL 활력은 황 결핍수준인 0 및 $0.1 \mathrm{mM}$ 에서만 유의적인 감소 $(\mathrm{p}<0.05)$ 를 보였다. 어린잎, 중간잎 및 뿌리 조직에서는 황 결핍수준이 증가함에 따라 글루타치온 함량은 유의적으로 증가 $(\mathrm{p}<0.05)$ 하였으나, 뿌 리에서는 처리간 유의적인 차이가 없었다. 황 공급수준의 감소에 따른 글루타치온 함량과 $\mathrm{SO}_{4}{ }^{2-}$ 흡수 간에는 고도의 정의 상관관계 $(\mathrm{p}<0.01)$ 가 인정되었으며, 잎과 뿌리내의 ATPS 및 잎조직의 OASTL 효 소활력 간에는 각각 부의 상관관계 $(\mathrm{p}<0.05)$ 가 인정되었다.
\end{abstract}

(Key words : Brassica napus, ATP sulfurylase, $O$-acteylserine(thiol) lyase, $\mathrm{SO}_{4}{ }^{2-}$ uptake, Glutathione, $\mathrm{S}$ supply level)

\section{I . INTRODUCTION}

Sulfur (S), as one of the most versatile elements in living organisms, is an essential mineral nutrient required for all living organs because it is an integral constituent of amino acids (cysteine, methionine) and various secondary sulfur compounds, such as glucosinolates, glutathione, thioredoxins, sulpholipids and several co-enzymes, which play an important role in the nutritional physiology and in the protection and adaptation of plants (Ruiz and Blumwald, 2002;

전남대학교(Chonnam National University, Gwangju 500-757, Korea)

* BK21 Research Team for the Control of Animal Hazards using Biotechnology, College of Agriculture \& Life Science, Chonnam National University, Gwangju 500-757, Korea

Corresponding author:Tae-Hwan Kim, Department of Animal Science, Institute of Agriculture Science and Technology, College of Agriculture \& Life Science, Chonnam National University, Gwangju 500-757, Korea. Tel: +82-62-530-2126, Fax: +82-62-530-2129, E-mail: grass1@ chonnam.ac.kr 
Hesse et al., 2004; Hawkesford and De Kok, 2006). It is well known that adequate $S$ supply may improve the pools of these compounds in plants that may lead to increase plant growth and dry mass (Saito, 2000; Prosser et al., 2001). Supplementary $\mathrm{S}$ fertilization to high $\mathrm{S}$ demanding crops such as Brassicas and legumes has shown to enhance plant stress-defense operations (Rausch and Wachter, 2005; Anjum et al., 2008) and improve $\mathrm{N}$ use efficiency and photosynthetic activity, growth and dry mass accumulation of crops since the accumulation of photoassimilates has a close relationship with $\mathrm{N}$ and $\mathrm{S}$ assimilation (Kopriva and Rennenberg, 2004; Hawkesford and De Kok, 2006). Thus, S nutrition may provide a novel strategy to reduce the adverse effect of plant stresses and in turn to improve plant growth and yield.

$\mathrm{S}$ is predominantly available to higher plants as sulfate $\left(\mathrm{SO}_{4}{ }^{2-}\right)$ taken up from soil by the roots. After $\mathrm{SO}_{4}{ }^{2-}$ is taken up via the root from the soil solution and transported by the xylem to the leaves. It is then reduced to adenosine-5'phosphosulfate (APS), and either converted to methionine or incorporated into cysteine, glutathione (GSH), and proteins (Saito 2000). The first metabolic transformation in the sulfur assimilation pathway is to generate adenosine-5'-phosphosulfate and pyrophosphate (PPi), catalyzed by ATPsulfurylase (ATPS). The major one of the two forms of ATPS is found in plastids and the other one is found in the cytoplasm(Leustek et al., 2000). The products, APS and PPi, must be converted to other compounds immediately so as to drive the former reaction. APS is mainly reduced to sulfite by adenosine-5'-phosphosulfate reductase (APR) with the present of GSH (Suter et al., 2000; Kopriva et al., 2002). The remaining APS is partially assimilate to PAPS (3'-phosphoadenosine-5'-phosphosulfate) by APS kinase and converts consequently to $O$-sulfated metabolites by sulfotransferase (Kopriva et al., 2002). Sulfite is further reduced to sulphide which is incorporated by $O$-acteylserine thiollyase (OASTL) into the amino acid skeleton of $\mathrm{O}$-acetylserine (OAS) to form cysteine (Kopriva and Rennenberg, 2004). $O$-acetylserine (OAS) is formed from serine catalyzed by serine acetyltransferase (Leustek et al., 2000). Cysteine can be incorporated into protein and utilized for further synthesis of methionine, coenzymes or GSH. Since the carbon skeleton of cysteine is derived from serine synthesized from both 3phosphoglycerate formed by the Calvin cycle in the chloroplast and from glycine formed by photorespiration in the mitochondria (Saito, 2000; Linka and Weber, 2005), it is deemed to be a central point of cellular metabolism of $\mathrm{GSH}$ synthesis. GSH, the tripeptide 8 -glutamylcysteinylglycine, is the most abundant low molecular thiol in plants and thus, the main storage and transport form of reduced sulfur. It plays an important role in the defense against various biotic or abiotic stress conditions (Ruiz and Blumwald, 2002) and is involved in redox homeostasis and detoxification (Leustek et al., 2000). GSH functions as reductant in the enzymatic detoxification of reactive oxygen species (ROS) in the ascorbate-GSH cycle and as thiol buffer in the protection of proteins via direct reaction with ROS or by the formation of mixed disulfides (Rausch and Wachter, 2005). Other physiological functions of GSH were deserved to the regulatory mechanism for sulfate uptake and assimilation controlled by the induction of sulfate transport system and key enzymes (Lappartient and Touraine, 1996 Lappartient et al., 1999) and by the level of transcription 
(Takahashi et al., 1997; Nikiforova et al., 2003). Lappartient and Touraine (1996) showed that the rate of $\mathrm{SO}_{4}{ }^{2-}$ uptake and the activity of ATP sulfurylase increased simultaneously in Brassica napus plants following $\mathrm{SO}_{4}{ }^{2-}$ withdrawal from culture solution, and then decreased after restoration of $\mathrm{SO}_{4}{ }^{2-}$ supply. These parallel patterns were also observed in split root experiments where the roots were continuously supplied with $\mathrm{SO}_{4}{ }^{2-}$, while the roots of the same plant where fed with an S-free medium (Lappartient et al., 1999). These results suggest that the regulation involves inter-organ signaling. It has been proposed that the signal responsible for the repression of $\mathrm{SO}_{4}{ }^{2-}$ uptake could be either internal $\mathrm{SO}_{4}{ }^{2-}$ (Smith, 1980; Datko and Mudd, 1984) or one of the products of its reduction, such as GSH (Rennenberg et al., 1989; Kopriva and Rennenberg, 2004). Reduced $\mathrm{S}$ molecules are translocated in the phloem (Schneider et al., 1994; Lappartient et al., 1999).

In these contexts, we hypothesized in this study that the change in GSH concentration as a result of different levels of $\mathrm{SO}_{4}{ }^{2-}$ supply might be associated with the control of $\mathrm{SO}_{4}{ }^{2-}$ uptake and assimilation. In order to test this hypothesis, GSH concentration was analyzed in leaves of different maturities and roots of rape plants supplied with four levels of external $\mathrm{SO}_{4}{ }^{2-}$ supply. The relationships of GSH concentration in leaves with $\mathrm{SO}_{4}{ }^{2-}$ uptake and the activity of key enzymes of $\mathrm{SO}_{4}{ }^{2-}$ assimilation were also assessed.

\section{П. MATERIALS AND METHODS}

\section{Plant culture and treatment}

Seeds of rape (Brassica napus L. cv. Mosa) were germinated in bed soil (containing peatmot, perlite, cocopeat, and zeolite 15:15:60:10, v/v). When plants were grown to the 3 leaves stage, they were transferred to $2.3 \mathrm{~L}$ pots filled with 2 $\mathrm{L}$ of complete nutrient solution. The basic nutrient solution contained $1 \mathrm{mM} \mathrm{NH} \mathrm{NO}_{3}, 0.5$ $\mathrm{mM} \mathrm{KH} \mathrm{KH}_{4}, 1.0 \mathrm{mM} \mathrm{K} \mathrm{HPO}_{4}, 1.5 \mathrm{mM} \mathrm{CaCl} 2$. $2 \mathrm{H}_{2} \mathrm{O}, 1.0 \mathrm{mM} \mathrm{MgSO}_{4}, 200 \mu \mathrm{M} \mathrm{Fe} \cdot \mathrm{Na} \cdot \mathrm{EDTA}$, and mixed micro-elements. The nutrient solution was continuously aerated and renewed every 5 days to minimize $\mathrm{pH}$ shifts and nutrient depletion. The seedlings were cultivated in a greenhouse with a day/night mean temperature of $27 / 20^{\circ} \mathrm{C}$, and a relative humidity of $65 / 80 \%$. Natural light was supplemented by metal halide lamps which generated approximately $400 \mu \mathrm{mol}$ photons $\mathrm{m}^{-2} \mathrm{~s}^{-1}$ at the canopy height for $16 \mathrm{~h}$ per day.

Eight-week-old plants with good uniformity were selected for the treatment of $\mathrm{SO}_{4}{ }^{2-}$ supply level. Four levels of $\mathrm{SO}_{4}{ }^{2-}(0,0.1,1.0$ and 2.0 $\mathrm{mM}$ ) were supplied by modifying the concentration of $\mathrm{SO}_{4}$ source in nutrient solution. For the solutions lacking $\mathrm{SO}_{4}{ }^{2-}$, as like 0 and 0.1 $\mathrm{mM}$, were used, $\mathrm{MgCl}_{2}$ was substituted for $\mathrm{MgSO}_{4}$. Three plants per treatment were harvested at 25 hour after treatment. Each plant was separated into old leaves, middle leaves, young leaves, and roots. Leaves were separated based on their ontogenic appearance defined as the leaf rank number which was orderedfrom the oldest to the youngest leaves. The old, middle and young leaves were designated, respectively, for the leaf rank number of 4-5, 8-9 and over 12. The tissue samples of each plant were immediately frozen in liquid $\mathrm{N}$ and stored in deep-freezer for further analysis.

\section{Determination of sulfate uptake}


Sulfateuptake was estimated by depletion method that determined the reduced concentration of specific ion in the complete nutrient solution. At the solution sampling time, the volume of nutrition solution was corrected to $400 \mathrm{ml}$ with distilled water, and then $2 \mathrm{ml}$ of well mixed solution was taken for analysis. The $\mathrm{SO}_{4}{ }^{2-}$ concentration in sample solution was determined using an ion chromatography (Dionnex, DX-120, USA) equipped with an Ionpac AS14A column and AG4A-SC guard column. The eluent solution consisted of $1.8 \mathrm{mM} \mathrm{Na}_{2} \mathrm{CO}_{3}$ and 1.7 $\mathrm{mM} \mathrm{NaHCO}_{3}$ and the regenerant of $0.025 \mathrm{~N}$ $\mathrm{H}_{2} \mathrm{SO}_{4}$. The flow rate was $2.3 \mathrm{ml} \mathrm{min}{ }^{-1} \cdot \mathrm{SO}_{4}{ }^{2-}$ uptake was determined by subtracting the current concentration at the sampling time from the initial concentration, and expressed as $\mu \mathrm{mol} \mathrm{SO}_{4}{ }^{2-}$ $\mathrm{g}^{-1}$ fresh weight (FW).

\section{Glutathione (GSH) measurement}

For the measurement of GSH concentration in shoot and root, $20 \mathrm{mg}$ fresh ground tissue was extracted by $1.0 \mathrm{ml} \mathrm{5 \%} 5$-sulfosalicylic acid. 900 $\mu \mathrm{l}$ reaction mixtures contained $143 \mathrm{mM} \mathrm{Na}-\mathrm{PO}_{4}$ buffer $(\mathrm{pH} \quad 7.5), \quad 6.3 \mathrm{mM} \quad \mathrm{Na}_{2}-$ Ethylenediaminetetraacetic acid(EDTA), $0.67 \mathrm{mM} \mathrm{5,5-Dithiobis}$ -2-nitrobenzoic acid (DTNB) and $0.22 \mathrm{mM}$ Nicotinamide adenine dinucleotide phosphate $\left(\mathrm{NADP}^{+}\right)$. Reaction was initiated with $100 \mu 1$ extracts by adding $10 \mu \mathrm{l}$ glutathione reductase. Changes in absorbance at $412 \mathrm{~nm}(\Delta \mathrm{A} 412 \mathrm{~nm})$ during 2 minutes were measured. Standard curve which was made with several different concentrations of GSH was used to calculate the concentration of GSH in plant samples.

\section{Enzyme assays}

About $200 \mathrm{mg}$ fresh tissues were quickly ground with liquid $\mathrm{N}$ with, then use $1.0 \mathrm{ml}$ extract buffer which contains $10 \mathrm{mM} \mathrm{Na}{ }_{2}$ EDTA, $20 \mathrm{mM}$ Tris- $\mathrm{HCl}(\mathrm{pH}$ 8.0), $2 \mathrm{mM}$ Dithiothreitol (DTT) and $1 \%$ polyvinylpyrrolidone (PVP), extract at $4^{\circ} \mathrm{C}$ with rotation about 1 hour followed by centrifugation at $13000 \mathrm{rpm}$ for 10 minutes at the same temperature. The resulting supernatant was used to determine the concentration of soluble proteins by protein-dye binding staining (Bradford, 1976). The supernatant was collected to analyze the ATP sulfurylase activity. Molybdate-dependent formation of pyrophosphate was measured to represent the activity of ATP-sulfurylase (Lappartient and Touraine 1996).

For the measurement of $O$-acetylserine (thiol) lyase (OASTL) activity, about $100 \mathrm{mg}$ fresh ground sample was extracted with $1.0 \mathrm{ml} 20$ $\mathrm{mM}$ Tris- $\mathrm{HCl}, \mathrm{pH}$ 7.5. The mixture was further homogenized and centrifuged for 10 minutes at 13,000 rpm. The final $1 \mathrm{ml}$ assay mixture for OASTL activity composed with $5 \mathrm{mM}$ OAS, 5 $\mathrm{mM} \mathrm{Na} 2 \mathrm{~S}, 33.4 \mathrm{mM}$ dithiotreitol, $100 \mathrm{mM}$ Tris$\mathrm{HCl}(\mathrm{pH}$ 7.5) and $50 \mu \mathrm{l}$ enzyme extract. The reaction was initiated by adding $\mathrm{Na}_{2} \mathrm{~S}$ and incubated for 30 minutes at $37^{\circ} \mathrm{C}$, then the reaction was terminated by adding $1 \mathrm{ml}$ acidic ninhydrin reagent $(0.8 \%$ ninhydrin $[\mathrm{w} / \mathrm{v}]$ in $1: 4$ concentrated $\left.\mathrm{HCl}: \mathrm{CH}_{3} \mathrm{COOH}\right)$. The mixture was heated at $100^{\circ} \mathrm{C}$ for 10 minutes to develop the color and then cooled on ice. The color complex was stabilized by adding $2 \mathrm{ml} 95 \%$ ethanol. Absorbance at $560 \mathrm{~nm}$ was read. The OASTL activity was interpreted by quantification of the enzymatically formed cysteine.

\section{Statistical Analysis}

A completely randomized design was utilized 
with three replicates. Duncan's multiple range test was employed to compare the means of separate replicates. Regression analysis was also undertaken to determine the closeness of relationship between the measured variables. Unless stated otherwise, the conclusions are predicted on differences between the means, with the significant level set at $\mathrm{P}=0.05$.

\section{RESULTS}

1. Effect of external $\mathrm{S}$ supply on $\mathrm{SO}_{4}{ }^{2-}$ uptake, ATP sulfurylase (ATPS) and $\mathrm{O}$ acetylserine (thiol) lyase (OASTL) activity

When plants were grown at four different $\mathrm{SO}_{4}{ }^{2-}$ concentrations for $25 \mathrm{~h}$, there was not profound effect on growth and appearance of forage rape plants (Data not shown). $\mathrm{SO}_{4}{ }^{2-}$ uptake, protein concentration and the activity of ATPS and OASTL in leaves and roots in response to the external $\mathrm{SO}_{4}{ }^{2-}$ supplied level are summarized at Table 1 . The $\mathrm{SO}_{4}{ }^{2-}$ uptake tended to increase with increasing external $\mathrm{S}$ supply. The $\mathrm{SO}_{4}{ }^{2-}$ uptake sharply increased (3fold increase) when external $\mathrm{SO}_{4}{ }^{2-}$ supply increased from $0.1 \mathrm{mM}$ to $1.0 \mathrm{mM}$, whereas only 1.2-fold between 1.0 and $2.0 \mathrm{mM}$. Protein concentration was not significantly changed by the external S supply level in both leaves and roots.

When $\mathrm{SO}_{4}{ }^{2-}$ was totally withdrawn from the nutrient solution ( $\left.0 \mathrm{mM} \mathrm{SO}{ }^{2-}\right)$, the activity of ATPS was 187.84 and $212.97 \mathrm{U} \mathrm{g}^{-1} \mathrm{FW}$, respectively, in leaf and root tissues. The ATPS activity in leaves supplied with $0.1,1.0$ and 2.0 $\mathrm{mM} \mathrm{SO}{ }_{4}{ }^{2-}$ decreased by $12.0,38.0$ and $45.2 \%$, respectively, compared to that of S-deprived treatment $\left(0 \mathrm{mM} \mathrm{SO}{ }_{4}{ }^{2-}\right)$, and decreased with a same way by $12.3,48.8$ and $58.3 \%$ in roots. The activity of OASTL tended to decrease as external S supply level was increased. When $\mathrm{SO}_{4}{ }^{2-}$ was deprived from the nutrient solution $\left(0 \mathrm{mM} \mathrm{SO}{ }_{4}{ }^{2-}\right)$, the OASTL activity in leaf and root tissues was 9.19 and $8.38 \mathrm{U} \mathrm{g}^{-1} \mathrm{FW}$, respectively. The OASTL activity in leaves supplied with $0.1, \quad 1.0$ and $2.0 \quad \mathrm{mM} \quad \mathrm{SO}_{4}{ }^{2-}$ decreased by $13.2,31.9$ and $34.5 .2 \%$, respectively, compared to that of S-deprived treatment. In roots, the OASTL activity was less varied, showing no significant difference between 0 and $0.1 \mathrm{mM}$ and also between 1.0 and $2.0 \mathrm{mM}$.

\section{Glutathione concentration in response to external S supply level}

Table 1. Sulfate uptake, protein concentration, ATP-sulfurylase (ATPS) and O-acetylserine (thiol) lyase (OASTL) activity in leaves and roots measured at $25 \mathrm{~h}$ after different $\mathrm{SO}_{4}{ }^{2-}$ supply levels

\begin{tabular}{|c|c|c|c|c|c|c|c|}
\hline \multirow{2}{*}{$\begin{array}{c}\mathrm{SO}_{4}{ }^{2-} \\
\text { Supply level }\end{array}$} & \multirow{2}{*}{$\begin{array}{l}\mathrm{SO}_{4}{ }^{2-} \text { uptake } \\
\left(\mu \mathrm{mol} \mathrm{g}{ }^{-1} \mathrm{FW}\right)\end{array}$} & \multicolumn{2}{|c|}{ Protein $\left(\mathrm{mg} \mathrm{g}^{-1} \mathrm{FW}\right)$} & \multicolumn{2}{|c|}{$\operatorname{ATPS}\left(\mathrm{U} \mathrm{g}^{-1} \mathrm{FW}\right)$} & \multicolumn{2}{|c|}{ OASTL $\left(\mathrm{U} \mathrm{g}^{-1} \mathrm{FW}\right)$} \\
\hline & & Leaves & Roots & Leaves & Roots & Leaves & Roots \\
\hline $0.0 \mathrm{mM}$ & - & $15.50^{\mathrm{ab}}$ & $9.88^{\mathrm{a}}$ & $187.84^{\mathrm{a}}$ & $212.97^{\mathrm{a}}$ & $9.19^{\mathrm{a}}$ & $8.38^{\mathrm{ab}}$ \\
\hline $0.1 \mathrm{mM}$ & $1.64^{\mathrm{c}}$ & $15.85^{\mathrm{ab}}$ & $9.39^{\mathrm{a}}$ & $165.23^{\mathrm{b}}$ & $186.84^{\mathrm{b}}$ & $7.97^{\mathrm{b}}$ & $9.62^{\mathrm{a}}$ \\
\hline $1.0 \mathrm{mM}$ & $4.98^{\mathrm{b}}$ & $16.62^{\mathrm{a}}$ & $9.35^{\mathrm{a}}$ & $116.37^{\mathrm{c}}$ & $109.01^{c}$ & $6.26^{\mathrm{c}}$ & $6.62^{c}$ \\
\hline $2.0 \mathrm{mM}$ & $5.81^{\mathrm{a}}$ & $16.79^{\mathrm{a}}$ & $9.18^{\mathrm{ab}}$ & $102.89^{\mathrm{d}}$ & $88.82^{\mathrm{d}}$ & $6.02^{\mathrm{c}}$ & $7.81^{\mathrm{bc}}$ \\
\hline
\end{tabular}

Values are the means of three replicates with three plants each. Values in a vertical column followed by different letters are significantly different at $\mathrm{P}<0.05$ according to Duncan's multiple range test. 
The changes in glutathione concentration in leaves being different maturities and roots as affected by the $\mathrm{SO}_{4}{ }^{2-}$ supplied level are presented at Fig. 1.

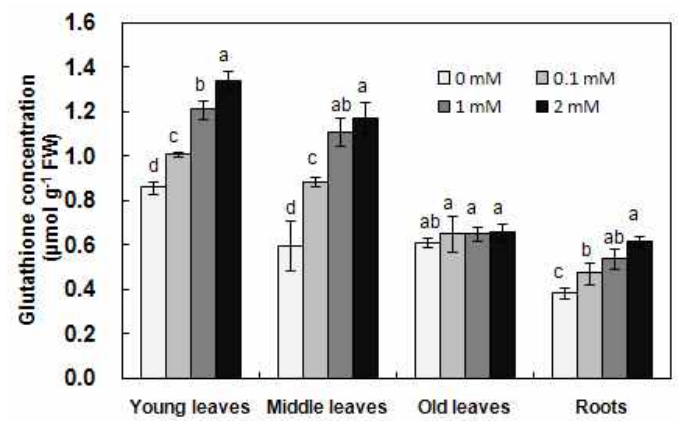

Fig. 1. Effect of the $\mathrm{SO}_{4}{ }^{2-}$ supplied level on glutathione concentration in the leaves at different maturities and roots. The measurement was done at $25 \mathrm{~h}$ after $S$ supply treatment. Bars labeled with different letters in a plant organ are significantly different $(p<0.05)$ according to Duncan's multiple range test.

The glutathione (GSH) concentrations in young leaves were relatively higher than that in other plant organs for all treatments of $\mathrm{S}$ levels applied, representing a range of $0.86 \sim 1.34 \mu \mathrm{mol}$ $\mathrm{g}^{-1} \mathrm{FW}$. In the youngest leaves and middle leaves, the GSH concentration significantly increased as the external S supply was increased. The GSH concentration in the youngest leaves supplied with $0.1, \quad 1.0$ and $2.0 \quad \mathrm{mM} \quad \mathrm{SO}_{4}{ }^{2-}$ increased by $27.9,40.6$ and $55.8 \%$, respectively, compared to that of S-deprived treatment $(0 \mathrm{mM}$ $\mathrm{SO}_{4}{ }^{2-}$ ). However, in the old leaves, no significant change was observed. The GSH concentration in the old leaves on average of four $\mathrm{S}$ levels was $43.4 \%$ lower than that in the young leaves. The GSH concentration in the roots also increased from 0.38 to $0.62 \mu \mathrm{mol} \mathrm{g}^{-1} \mathrm{FW}$ as the external $\mathrm{S}$ supply was increased from 0 to $2.0 \mathrm{mM}$.

\section{Relationship of glutathione concentration with $\mathrm{SO}_{4}{ }^{2-}$ uptake and assimilation}

Correlation between glutathione (GSH) concentration and $\mathrm{SO}_{4}{ }^{2-}$ uptake, as affected by the $\mathrm{SO}_{4}{ }^{2-}$ levels supplied, were assessed (Fig. 2A). The increase in $\mathrm{SO}_{4}{ }^{2-}$ uptake by the increased $\mathrm{SO}_{4}{ }^{2-}$ supply was strongly associated with an enhancement of GSH in leaves $(r=0.797, p<0.01)$ and in roots $(\mathrm{r}=0.718, \mathrm{p}<0.01)$. To examine further the physiological significance of $\mathrm{GSH}$ accumulation in shoot in regulating $\mathrm{SO}_{4}{ }^{2-}$ assimilation, the relationships of GSH concentration

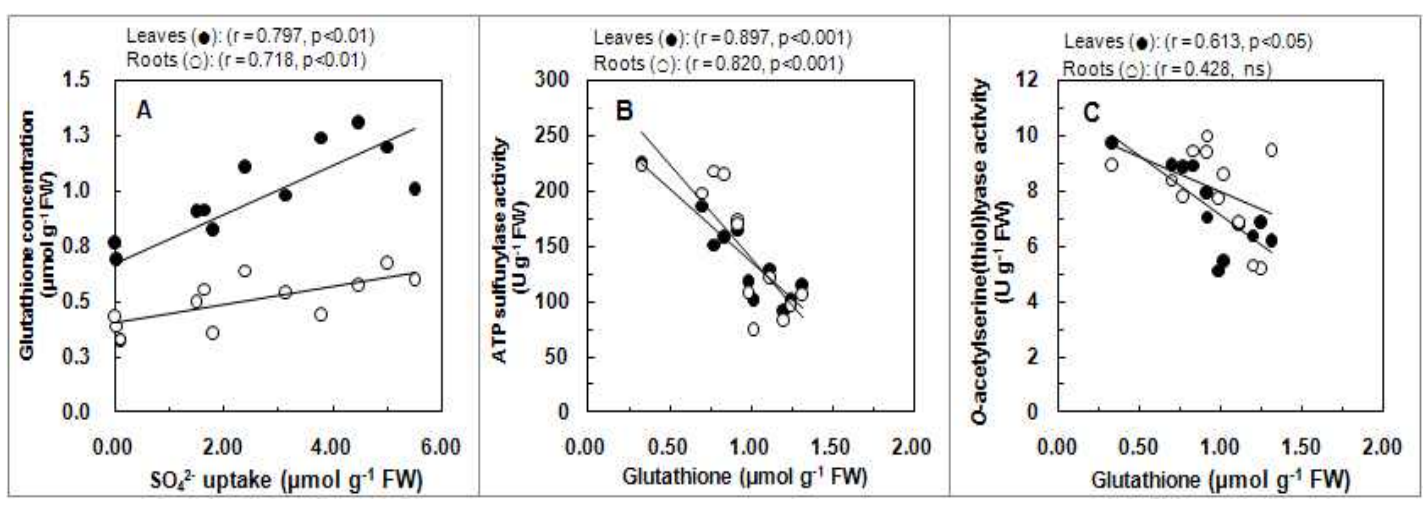

Fig. 2. The relationships of glutathione concentration, as affected by the external $S$ supply level, with (A) $\mathrm{SO}_{4}{ }^{2-}$ uptake, (B) ATP sulfurylase and (C) O-acetylserine (thiol) lyase activity in leaves (closed symbols) and roots (open symbols) $(n=12)$. 
in leaves with the activity of ATPS (Fig. 2B) and OASTL (Fig. 2C) were also analyzed. As indicated at Fig. 2B, the increase in endogenous GSH concentration, affected by the $\mathrm{SO}_{4}{ }^{2-}$ supply level, was significantly related with the decrease in ATPS activity in leaves $(r=0.897$, $\mathrm{p}<0.001)$ and $\operatorname{roots}(\mathrm{r}=0.820, \quad \mathrm{p}<0.001)$. The relationship of GSH concentration with OASTL activity in leaves was also significant $(r=0.613$, $\mathrm{p}<0.05$ ), but not with OASTL activity in roots.

\section{DISCUSSION}

The $\mathrm{SO}_{4}{ }^{2-}$ uptake was well reflected on the external $\mathrm{SO}_{4}{ }^{2-}$ supply level (Table 1). Total $\mathrm{S}$ concentration in the leaves is closely paralleled with $\mathrm{SO}_{4}{ }^{2-}$ concentration in the nutrient solution (Mechteld et al., 1998). These results suggest that uptake and subsequent distribution of $\mathrm{SO}_{4}{ }^{2-}$ to the leaves are closely associated with Sdemand and S-status in plant tissues. In the previous study ( $\mathrm{Li}$ et al. 2009), we reported that sulfate distribution and accumulation in the old matured leaf might be the first magnitude, and that the percentage of decrease in $\mathrm{SO}_{4}{ }^{2-}$ concentration caused by S-deficiency or Sdeprivation was the highest in the young leaves, even though the absolute concentration was lowest among leaf tissues. It has been widely documented that there is a clear difference in the distribution of sulfur between leaves of different ages (Smith, 1980 Blake-Kalff et al., 1998; Prosser et al., 2001), suggesting that $\mathrm{SO}_{4}{ }^{2-}$ assimilation in response to the external $\mathrm{S}$ supply reflects a sink-source relationship for their metabolites among different ages of leaf. We previously reported thatthe activities of ATP sulfurylase (ATPS) and adenosine 5' phosphosulphate reductase (APR) in the young leaves were higher than in the matured old leaves, and the changes in enzymes activity to the external $\mathrm{S}$ supply level was the most distinct in the young leaves ( $\mathrm{Li}$ et al., 2009). The present data also showed that ATPS and $O$-acetylserine (thiol) lyase (OASTL) activity in leaves was significantly restricted as the external S supply was increased (Table 1). In the oil seed rape plants supplied with a sufficient external $\mathrm{S}$ supply, approximately $50 \%$ of total $\mathrm{S}$ in the youngest leaves was incorporated into insoluble $\mathrm{S}, 2 \%$ into $\mathrm{GSH}, 6 \%$ into glucosinolates, and $42 \%$ accumulated as $\mathrm{SO}_{4}{ }^{2-}$, whereas in the oldest leaves $70 \%$ to $90 \%$ of $\mathrm{S}$ accumulated as $\mathrm{SO}_{4}{ }^{2-}$ (Blake-Kalff et al. 1998). It has been reported that in soybean plants, $\mathrm{SO}_{4}{ }^{2-}$ in the transpiration stream was predominantly delivered to developing leaves, despite the fact that matured and young leaves transpired at an equal rate (Smith and Lang, 1988). In this study, GSH concentrations, which an immediate $\mathrm{S}$ assimilates, in the young and the middle leaves were much higher than those in old leaves or roots, and the GSH concentration in the young leaves significantly decreased (Fig. 1) with a concomitant decrease in the activity of ATPS and OASTL (Table 1) as external $\mathrm{SO}_{4}{ }^{2-}$ supply was lowered. These suggested that the active site of $\mathrm{SO}_{4}{ }^{2-}$ assimilation might be young tissue rather than old or mature leaf tissues, and sulfate metabolism would be much more restricted by S-limited nutrition. It has long been known that $S$ starvation results in a strong increase of the activity of ATPS and APR in plant cells (Reuveny et al., 1980) and on the whole plant level (Lappartient et al., 1999). The increase in steady-state levels of mRNAs for high affinity sulfate transporters, ATPS, and APR upon S starvation, has been detected by northern 
analysis (Takahashi et al., 1997) or cDNA array (Nikiforova et al., 2003). The consequences of $\mathrm{S}$ starvation was most pronounced in the enzymes involved in the uptake and assimilation of $\mathrm{SO}_{4}{ }^{2}$ -, but the synthesis of the amino acid acceptor $O$ - actylserine also seemed to be influenced (Takahashi et al., 1997). On the other hand, the OASTL activity was reported either to be reduced by $\mathrm{S}$ deficiency in spinach (Warrilow and Hawkesford, 1998) or not to be affected (Smith, 1980; Takahashi and Saito, 1996).

In this study, the increase in $\mathrm{SO}_{4}{ }^{2-}$ uptake, which was attributed to the increased $\mathrm{SO}_{4}{ }^{2-}$ supply, was strongly associated with an enhancement of GSH in both leaves and roots (Fig. 2A). Blake-Kalff et al. (1998) suggested that in the oil seed rape plants grown on plus $\mathrm{S}$ and low $\mathrm{N}$, the surplus of $\mathrm{S}$ resulted in the accumulation of GSH or glucosinolates. The GSH synthesis of plant cells is dependent on and regulated by the $\mathrm{S}$ supply. During $\mathrm{S}$ deficiency GSH content rapidly decreased in tobacco cell cultures but was rebuilt upon the supply of $\mathrm{SO}_{4}{ }^{2-}$ and cysteine (Smith, 1980). It has been proposed that GSH acts as a regulatory signal to decrease the $\mathrm{SO}_{4}{ }^{2-}$ uptake in the roots (Rennenberg et al., 1989; Lappartient and Touraine, 1996). Conducting spilt-root experiment in Brassica napus, Lappartient and Touraine (1996) have demonstrated that the regulation of ATPS protein and mRNA underlies the responses of root ATPS activity to $S$ depletion. The present data showed that the increased GSH concentration in leaves, as a consequence of the $\mathrm{SO}_{4}{ }^{2-}$ uptake increased by a high external supply, was significantly related with the decreased activity of ATPS in leaves and roots (Fig. 2B) and OASTL activity in leaves (Fig. 2C). These results well reflects the earlier works in Brassica napus (Lappartient and Touraine, 1996) which suggested that the control of root ATPS activity and $\mathrm{SO}_{4}{ }^{2-}$ uptake is mediated by phloem-translocated GSH. Consistent with these suggestions, the abundance of transcripts in S-starved plants was increased, and GSH feeding resulted in a decline in transcript levels (Lappartient et al., 1999).

Taken together, $\mathrm{SO}_{4}{ }^{2-}$ uptake and assimilation are closely associated with the GSH concentration and the operating process enables plants to respond with general flexibility to fluctuation of $\mathrm{S}$ availability in root environment. If so, it would be an important component for the development of field diagnostic tests to determine whether plants are S-deficient.

\section{ABSTRACT}

The glutathione (GSH) concentration in leaves of different maturities and roots of forage rape (Brassica napus L.) supplied with four levels of external $\mathrm{SO}_{4}{ }^{2-}(0,0.1,1.0$ and $2.0 \mathrm{mM})$ supply were measured. The relationships of $\mathrm{GSH}$ concentration with $\mathrm{SO}_{4}{ }^{2-}$ uptake, ATP sulfurylase (ATPS) and $O$-acteylserine (thiol) lyase (OASTL) activity were also assessed. The $\mathrm{SO}_{4}{ }^{2-}$ uptake increased in parallel with the external $\mathrm{SO}_{4}{ }^{2-}$ supply, while protein concentration was not significantly changed. The ATPS activity increased continuously with decreasing $\mathrm{SO}_{4}{ }^{2-}$ supply from 2.0 to $0 \mathrm{mM}$, while the OASTL activity decreased significantly only at S-deficient conditions ( 0 and $0.1 \mathrm{mM})$. The GSH concentration in the young leaves, middle leaves and roots continuously increased (except for between 1.0 and $2.0 \mathrm{mM}$ in the middle leaves and roots) as the external S supply was increased, but no significant changes occurred in the old leaves. 
The increased endogenous GSH concentration, affected by the $\mathrm{SO}_{4}{ }^{2-}$ supply level, was significantly related with the decrease in ATPS activity in both leaves and roots, and the decrease in OASTL activity only in leaves..

\section{ACKNOWLEDGEMENT}

"This work was supported by the Korea Research Foundation Grant.”(KRF-2009-013F00004)

\section{REFERENCES}

1. Anjum, N.A., S. Umar, A. Ahmad, M Iqbal and N.A. Khan. 2008. Sulphur protects mustard (Brassica compestris L.) from cadmium toxicity by improving leaf ascorbate and glutathione. Plant Growth Regul. 54:271-279.

2. Blake-Kalff, M.M.A., K.R. Harrison, M.J. Hawkesford, F.J. Zhao and S.P. McGrath. 1998. Distribution of sulfur within oilseed rape leaves in response to sulfur deficiency during vegetative growth. Plant Physiol. 118:1337-1344.6.

3. Bradford, M.M. 1976. A rapid method for the quantificatio of microgram quantities of protein utilizing the principle of protein-dye binding. Anal. Biochem. 72:248-254.

4. Datko, A.H. and S.H. Mudd. 1984. Sulfate uptake and its regulation in Lemna paucicostata Hegelm 6746. Plant Physiol. 75:466-473.

5. Hawkesford, M.J. and L.J. De Kok. 2006. Managing sulphur metabolism in plants. Plant Cell Environ. 29:382-395.

6. Hesse, H., V. Nikiforva, B. Gakiere and R. Hoefgen. 2004. Molecular analysis and control of cysteine biosynthesis: Integration of nitrogen and sulfur metabolism. J. Exp. Bot. 55:1283-1292.

7. Kopriva, S., T. Buchert, G. Fritz, M. Suter, R. Benda, V. Schunemann, A. Koprivova, P. Schurmann, A. X. Trautwein, P.M.H. Kroneck and C. Brunold. 2002. The presence of an iron-sulfur cluster in adenosine 5'-phosphosulfate reductase separates organisms utilizing adenosine 5'-phosphosulfate and phosphoadenosine 5'-phosphosulfate for sulfate assimilation. J. Biol. Chem. 277: 21786-21791.

8. Kopriva, S. and H. Rennenberg. 2004. Control of sulphate assimilation and glutathione synthesis: interaction with $\mathrm{N}$ and $\mathrm{C}$ metabolism. J. Exp. Bot. 55:1831-1842.

9. Lappartient, A.G. and B. Touraine. 1996. Demanddriven complete solution of root ATP sulfurylase activity and $\mathrm{SO}_{4}{ }^{2-}$ uptake in intact canola. Plant physiol. 111:147-157.

10. Lappartient, A.G., J.J. Vidmar, T. Leustek, A.D.M. Glass and B. Totraine. 1999.Inter-organ signaling in plants: regulation of ATP sulfurylase and sulfate transporter genes expression in roots mediated by phloem-tranlocated compound. Plant J. 18: 89-95.

11. Leustek, T., M.N. Martin, J.A. Bick and J.P. Davies. 2000. Pathways and regulation of sulfur metabolism revealed through molecular and genetic studies. Annu. Rev. Plant Physiol. Plant Mol. Biol. 51:141-165.

12. Li, L.S., Y.L. Jin, B.R. Lee and T.H. Kim. 2009. Sulfur deficiency effects on sulfate uptake and assimilatory enzymes activity in rape plants. J. Kor. Grass. Forage Sci. 29(2):95-102.

13. Linka, M. and A.P.M. Weber. 2005. Shuffling ammonia between mitochondria and plastids during photorespiration. Trends Plant Sci. 10: 461-465.

14. Mechteld, M., A. Blake-Kalff, R. Kevin, M.J. Hawkesford, J.F. Zhao and S.P. McGrath. 1998. Distribution of sulfur within oilseed rape leaves in response to sulfur deficiency during vegetative growth. Plant Physiol. 118:1337-1344.

15. Nikiforova, V., J. Freitag, S. Kempa, M. Adamik, H. Hesse, R. Hoefgen. 2003. Transcriptome analysis of sulfur depletion in Arabidopsis thaliana: interlacing of biosynthetic pathways provides response specificity. Plant J. 33:633-650.

16. Prosser, I.M., J.V. Purves, L.R. Saker and D.T. Clarkson. 2001. Rapid disruption of nitrogen metabolism and nitrate transport in spinach plants deprived of sulphate. J. Exp. Bot. 52:113-121.

17. Rausch, T. and A. Wachter. 2005. Sulfur metabolism: a versatile platform for launching defence 
operations. Trends Plant Sci. 10:503-509.

18. Rennenberg, H., O. Kemper and B. Thoene. 1989. Recovery of sulfate transport into hetrotrophic tobacco cells from inhibition by reduced glutathione. Physiol. Plant. 76:271-276.

19. Reuveny, Z., D.K. Dougall, P.M. Trinity. 1980. Regulatory coupling of nitrate and sulfate assimilation pathways in cultured tobacco cells. Proc. Natl Acad. Sci. USA. 77:6670-6672.

20. Ruiz, J.M. and E. Blumwald. 2002. Salinityinduced glutathione synthesis in Brassica napus. Planta. 214:965-969.

21. Saito, K. 2000. Regulation of sulfate transport and synthesis of sulphur-containing amino acids. Curr. Opin. Plant Biol. 3:188-195.

22. Schneider, A., T. Schatten and H. Rennenberg. 1994. Exchange between phloem and xylem during long distance transport of glutathione in spruce trees (Picea abies L). J. Exp. Bot. 45:457462.

23. Smith, I.K. 1980. Regulation of sulfate assimilation in tobacco cells. Effect of nitrogen and sulfur nutrition on sulfate permease and $O$ acetylserine sulfurylase. Plant Physiol. 66:877883.

24. Smith, I. K. and A. L. Lang. 1988. Translocation of sulphur in soybean(Glycine $\max$ L. Merr). Plant Physiol. 86:798-802.

25. Suter, M., P. Ballmoos, S. Kopriva, R.O. Camp, J. Schaller, C. Kuhlemeier, P. Schürmann and C. Brunold. 2000. Adenosine 5'-phosphosulfate sulfotransferase and adenosine 5'-phosphosulfate reductase are identical enzymes. J. Biol. Chem. 275:930936.

26. Takahashi, H. and K. Saito. 1996. Subcellular localization of spinach cysteine synthase isoforms and regulation of their gene expression by nitrogen and sulfur. Plant Physiol. 112:273-280.

27. Takahashi, H., M. Yamazaki, N. Sasakura, A. Watanabe, T. Leustek, J. de Almeida Engler, G.. Engler, M. van Montagu. K. Saito. 1997. Regulation of sulfur assimilation in higher plants: a sulfate transporter induced in sulfate-starved roots plays a central role in Arabidopsis thaliana. Proc. Natl Acad. Sci. USA. 94:11102-11107.

28. Warrilow, A.G.S and M.J. Hawkesford. 1998. Separation, subcellular location and influence of sulfur nutrition on isoforms of cysteine synthase in spinach. J. Exp. Bot. 49:1625-1636.

(접수일: 2011년 1월 28일, 수정일 1차: 2011년 2월 14일, 수정일 2차: 2011년 3월 8일, 게재확정일: 2011년 3월 15일) 